\title{
Under CIVILIAN COLONELS: Indigenous Political Mobilization in 1920s Ayacucho, Peru
}

W ith his television blaring in the corner, Don Isidro Durán spoke of the men whom his neighbors had once chosen as leaders, men those neighbors labeled "colonels." As Don Isidro described the indigenous political mobilization that rocked his rural Ayacucho community back in 1923, he explained that these colonels led their supporters in military exercises and proclaimed that President Augusto B. Leguía was "bad for the Pueblo." Although the elderly Durán spoke with the authority of an eyewitness and the eloquence of a local intellectual, the indigenous leaders he described are essentially absent from the extensive literature on indigenous politics during Peru's 1920s. ${ }^{2}$ That absence is surprising, for reports of various popularly appointed colonels fill Ayacucho's archival records during Leguía's oncenio (his 1919-1930 presidency). These Ayacuchano civilian colonels were typically literate, indigenous men without formal standing in the Peruvian armed forces. During the first years of the $1920 \mathrm{~s}$, Ayacucho peasants embraced these indigenous men as leaders because of their profound anger at official government authorities and their agents. Ayacucho's civilian colonels channeled this popular anger into specific acts of protest, and that protest often-although not always - was militaristic in form and function. Strikingly, these indigenous political leaders had significant connections to one

I extend my heartfelt thanks to the two anonymous reviewers for The Americas for their thoughtful suggestions and to Steven Pent for providing me with a copy of his M.A. thesis.

1. Interview with Isidro Durán (Carhuanca, March 14, 2003). Isidro Durán is a pseudonym.

2. This literature has typically focused on either Puno or Cuzco. Key works include Marcela Calisto, "Peasant Resistance in the Aymara Districts of the Highlands of Peru, 1900-1930: An Attempt at Self-Governance" (PhD dissertation, University of California at San Diego, 1993); Annalyda Álvarez-Calderón, "Es justicia lo que esperamos de Su Excelencia: Política indígena en Puno (1901-1927)," in Más alla de la dominación y la resistencia: Estudios de bistoria peruana, siglos $x v i-x x$, Leo Garofalo and Paulo Drinot, eds. (Lima: IEP, 2005), pp. 312-341; Dan Hazen, "The Awakening of Puno: Government Policy and the Indian Problem in Southern Peru, 1900-1955" (PhD dissertation: Yale University, 1974); José Luis Rénique, La batalla por Puno: conflicto agrario y nación en los Andes Peruanos, 1866-1995 (Lima: IEP, 2004); José Luis Rénique, Los steños de la sierra: Cusco en el siglo XX (Lima: CEPES, 1991). For a broader national perspective, see Wilfredo Kapsoli, Los movimientos campesinos en el Perii, 1879-1965 (Lima: Ediciones Atusparia, 1977); Jorge Basadre, Historia de la república del Perí, 1822-1933 (Lima: Editorial Universitaria, 1983). Paulo Drinot's forthcoming edited collection Nuevas perspectivas sobre el oncenio (Lima: IEP, 2010) will greatly advance historiographical discussions of Leguía's presidency. 
another. They communicated and collaborated across a broad geographical territory, forming a political web that stretched across community, district and even provincial boundaries.

To organize this discussion, I structure my arguments around the case of just one of these colonels: an indigenous campesino named Juan Nieto. Under Colonel Nieto's command, around 300 indigenous campesinos from the Cangallo, Ayacucho community of Llaccolla entered the nearby community of Concepción on September 7, 1923. Numerous Concepción residents immediately joined the ranks of the Llaccolla peasants, and together, these campesinos headed to the home of Juan Pablo Vila, the local representative of the Tax Collection Company (Compañia Recaudadora de Impuestos). The group-dubbed montoneras (irregular troops) by observers-took Vila from his home, and marched him out of the community. Over the next eight days, the Llaccolla and Concepción campesinos led Vila to the community of Pampas in the neighboring province of La Mar, where they imprisoned and then executed him. As an indigenous woman named Jesusa Martínez testified at the ensuing murder trial, the montoneras made Vila suffer his "horrible death" because "he was a thief of the pueblo [ladrón del pueblo], he levied taxes on them, even though the fiscal taxes did not exist." 3

On first glance, the protest under Colonel Nieto looks like little more than a small antitax revolt by peasants. But a close examination of the testimonies given at Nieto's trial reveals that there was much, much more to the events of September 1923 than opposition to taxes alone. Looking at the explanations offered by witnesses, and placing those explanations in the context of other indigenous campesinos' words and actions from oncenio-era Ayacucho, it becomes clear that the protest under Colonel Nieto was part of a broad range of rural mobilizations against abusive authorities in rural Ayacucho. More interesting still, the Llaccolla and Concepción montoneras had deep linkages to many of those other mobilizations. And like the Llaccolla and Concepción campesinos, these other mobilized peasants often militarized their political activism.

The story of Ayacucho's civilian colonels offers a new perspective on the recent historical debate about indigenous rebellions in 1920s Peru. In her brilliant book Indigenous Mestizos, anthropologist Marisol de la Cadena critiques "the historiographic production of indigenous messianic rebellions." 4 She asserts that numerous historians inaccurately cast indigenous activism in the 1920 s as violent uprisings, reproducing the heated claims of local elites and ignoring indigenous fol. 13

3. Archivo Regional de Ayacucho (ARA), Corte Superior de Justicia (CSJ), legajo (leg.) 407, cuaderno (cuad.) 1,

4. Marisol de la Cadena, Indigenous Mestizos: The Politics of Race and Culture in Cuzco, 1919-1991 (Durham: Duke University Press, 2000), p. 118. 
actors' denials of violence. To de la Cadena, indigenous political actions in the 1920 s amounted to peaceful efforts for citizenship rather than violent acts of rebellion. Events in Ayacucho, however, reveal that many indigenous men and women tread a course between the poles of violent and nonviolent political activity during the oncenio. The very same individuals who militarized their political activities and engaged in bloody protests also undertook decidedly pacific political actions like writing letters and holding meetings to discuss government policies. In their letters and court testimonies, indigenous men and women described the broad range of their political actions, and their own words reveal a spectrum of political action that stretched from nonviolence to violence. These creative political fusions of militaristic and peaceful political tactics were far from unique in the Peruvian context. Treating the much earlier period of the 1780 s, historian Charles Walker described the "intimate relationship between armed rebellion and the use of the courts," showing how Cuzco's indigenous peasants simultaneously combined peaceful and violent political tactics. ${ }^{5}$ The case of Ayacucho's civilian colonels, as with indigenous rebels in the eighteenth century, suggests that the lines between violent and nonviolent political actions were often far from absolute.

Campesinos' political connections across geographical space, in turn, compel a rethinking of the character of oncenio-era indigenous mobilization. Although scholars have moved far beyond depictions of peasants as strictly parochial political actors, we have not fully examined the political relationships and partnerships that connected indigenous campesinos across broad territorial stretches. ${ }^{6}$ Several historians have begun exploring those connections for the 1920s through their considerations of the Comite Pro-Derecho Indígena Tawantinsuyo (the ProIndian Rights Tawantinsuyo Committee). ${ }^{7}$ Andean men and women from departments across Peru's sierra joined this indigenous rights organization as departmental delegates and provincial subdelegates, and many of these delegates participated in the Committee's national congresses in Lima. Through their involvement in the Tawantinsuyo movement, indigenous men and women established Committee-based political linkages that reached across departments, provinces, rural communities and cities. The experiences of Ayacucho's civilian colonels, however, demonstrate that campesinos' broad political connections in

5. Charles Walker, Smoldering Ashes: Cuzco and the Creation of Republican Peru, 1780-1840(Durham: Duke University Press, 1999), p. 56.

6. See Florencia Mallon's work, Peasant and Nation: The Making of Postcolonial Mexico and Peru (Berkeley: University of California Press, 1995), for a discussion of peasant nationalism.

7. Wilfredo Kapsoli Escudero, Ayllus del sol: anarquismo y utopa andina (Lima: TAREA, 1984), pp. 197-244; de la Cadena, Indigenous Mestizos, pp. 86-130; Jaymic Patricia Heilman, "By Other Means: Politics in Rural Ayacucho before Peru's Shining Path War, 1879-1980" (PhD dissertation, University of Wisconsin at Madison, 2006), pp. 108166; Steven Eric Pent, "Bridging the Urban-Rural Divide: Mobilization and Citizenship of a Peruvian Peasant Organization" (M.A. thesis, University of California at Santa Barbara, 2007). 
this era transcended participation in the Tawantinsuyo Committee. Inside Ayacucho, indigenous peasants and their leaders formed a far-reaching political network of communication and collaboration. Rural Ayacuchanos' extensive political web reveals that indigenous men and women readily forged partnerships across the borders of their communities, districts, and even provinces. By recognizing campesinos' extensive political networks, we can once again challenge Eric Hobsbawm's argument that peasants' horizons are limited to that of parish pump, on one hand, or the supernatural, on the other, with nothing in between. ${ }^{8}$

The case of Ayacucho's civilian colonels and their protests also provides fresh insights into indigenous peasants' attitudes toward taxation. To carry out his grand plan of transforming Peru into a Patria Nueva, a New Fatherland, President Augusto B. Leguía introduced massive public works projects and a dramatic expansion of the government bureaucracy, funded by loans, investments, and taxes. ${ }^{9}$ As was true in many other moments of Peruvian history, the government's tax policies generated considerable opposition in the countryside. Although the role of antitax anger in the protests of indigenous Peruvian peasants has preoccupied many historians, this article adds a new twist on the old antitax story: many indigenous campesinos in 1920s Ayacucho were angered less by taxes that did exist than by the unjust imposition of taxes they believed did not exist. ${ }^{10}$ Their anger, then, was not at authorities for levying taxes, but instead at duplicitous authorities for lying about taxes. Governmental corruption, rather than economic insensitivity, was the problem. To twist the words of E.P. Thompson-and, by extension, James C. Scott-what took place in rural Ayacucho was not about the "moral economy" of the peasant, but rather about campesinos" vision of "moral politics." rupt and dishonest authorities and to establish a new model of just and ethical political leadership.

Finally, this article takes up historian Cecilia Méndez's call for a reconsideration of the place of militarism in the lives of Peruvian campesinos. Méndez rightly notes that although militarism has long pervaded rural life in Peru-from weekly marches to flag raising ceremonies to the singing of the national anthem-historians have yet to consider rural Peruvian militarism from a socio-cultural angle. Instead, historians have too narrowly conceptualized peasant-military relations in

8. A critique of Hobsbawm appears in Mark Thurner, From Two Republics to One Divided: Contradictions of Postcolonial Nationmaking in Andean Peru (Durham: Duke University Press, 1997), pp. 137-138. 242-244.

9. Peter F. Klarén, Perw: Society and Nationhood in the Andes (New York: Oxford University Press, 2000), pp.

10. See, for example, the debate about rural tax protests in Thurner, From Two Republics, p. 82.

11. See E.P. Thompson, "The Moral Economy of the English Crowd in the Eighteenth Century," Past and Present 50 (February 1971), pp. 76-136; James C. Scott, The Moral Economy of the Peasant: Rebellion and Resistance in Southeast Asia (New Haven: Yale University Press, 1976). 
terms of (military) repression and (peasant) resistance. ${ }^{12}$ Yet whereas Méndez proposes a study of the historical relationships between the official Peruvian military and the country's campesinos, this article looks in a different direction, examining indigenous peasants' popular militarism. Indigenous peasants in Leguía-era Ayacucho often incorporated the forms and features of military organization into their civilian mobilizations, calling themselves montoneras and their leaders colonels.

\section{Opposition to Abusive Authorities}

Indigenous men and women living in Ayacucho's countryside embraced the leadership of civilian colonels at a political moment defined by bitter popular enmity toward government officials and their agents, including employees of the government-contracted Tax Collection Company. ${ }^{13}$ The Llaccolla and Concepción protesters who killed Juan Pablo Vila acted under the leadership of an indigenous peasant named Juan Nieto, a man they deemed Colonel. An employee of the Tax Collection Company testified that the Llaccolla and Concepción campesinos who killed Vila were "at the command of the titular Colonel Juan Nieto."14 Jesusa Martínez likewise testified that the protesters acted "under the leadership of the titular Colonel Nieto." 15 Witnesses' stress on the qualifying adjective "titular" suggest that Colonel Nieto was not a formal member of the Peruvian armed forces, although he may well have performed military service at an earlier point in his life. Whatever his past experience in the military, Colonel Nieto emerged as a leader who guided popular local anger at government authorities and representatives into a concrete protest.

The depth of rural Ayacuchano anger at political authorities in this era cannot be overstated, and that anger indeed emerged as one explanation for the uprising under Colonel Nieto's leadership. One witness at Colonel Nieto's trial testified that the Llaccolla/Concepción protest was "against educated persons and the authorities in general." 16 Jesusa Martínez, in turn, explained that the Llaccolla rebels had sent word of their plans several days before they entered Concepción, relaying that they were going to "oust all the local notables." 17 To "oust all the

12. Cecilia Méndez, "Las paradojas del autoritarismo: ejército, campesinado, y etnicidad en el Perú, siglos XIX al XX," Iconos: Revista de Ciencias Sociales 26 (September 2006), pp. 17-34.

13. Details on the fiscal arrangement between the Peruvian State and the Tax Collection Company appear in Carlos Contreras, "The Tax Man Cometh: Local Authorities and the Battle Over Taxes in Peru, 1885-1906," in Political Cultures in the Andes, 1750-1950, Nils Jacobsen and Cristóbal Aljovín de Losada, eds. (Durham: Duke University Press, 2005), pp. 116-136.

14. ARA, Pref. Oficios de la Compañía Recaudadora de Impuestos (OCRI) leg. 108 (Oficio 690: September 20,1923).

15. ARA, CSJ, leg. 407, cuad. 1, fol. 11.

16. ARA, CSI, leg. 407, cuad. 1 , fol. 35 .

17. ARA, CSJ, leg. 407, cuad. 1, fol. 111 . 
local notables" essentially meant to "oust all the local authorities" for within Ayacuchano vernacular of the $1920 \mathrm{~s}$, and throughout most of the twentieth century, "local notables" referred to the wealthiest, literate members of rural communities, usually the largest landowners, priests, and teachers, who cycled in and out of positions of government authority at the district level.

Rural indigenous anger at oncenio-era authorities was in fact so considerable that many departmental authorities abandoned their posts, fearing for their lives. Cangallo's examining magistrate (juez de primera instancia) telegrammed the general director of justice in September 1923, relaying that he was "obligated to retreat" due to the "lack of guarantees" in the face of "indigenous pueblos' movements that threaten to invade this town." 18 The governor of Huambalpa, Severino Lara, likewise abandoned his post, "due to threats from the subversives." 19 The governor of Chilcas, in turn, resigned from his post in 1923, explaining that he could not provide his services as a political authority given the local context of "subversive Indians and danger to my life and interests." 20 One man even refused to accept his appointment to the position of governor. Manuel Roca explained that "in last year's uprising, I was called by the ringleaders of the indigenous movement, where they made me swear never to assume any post." For that reason, Roca declined to be named governor of Chungui, as it would make him "hated in this Pueblo."21

Of the many accusations Ayacuchano campesinos levied against their authorities, one charge arose with particular frequency: corruption. Anger at assumed corruption was a key factor driving Colonel Nieto's protest. A first clue to this motivation comes with Jesusa Martínez's words, quoted above. As Martínez testified, Vila died because he was a "thief of the pueblo," levying taxes that Llaccolla and Concepción campesinos (incorrectly) believed no longer existed. Her words offer an important qualifier: to his killers, Vila's crime was not the collection of actual taxes. Instead, his crime was demanding the payment of fictitious taxes. Vila's crime, then, was one of fraud and dishonesty. Jesusa Martínez was not the only witness to present this explanation. Concepción resident Simeón Cárdenas explained that the montonera had risen up because the fiscal taxes had been abolished, and "only the employees of the Tax Company and educated persons were demanding them. Even the tax on salt no longer existed."22 Guillermo Quintanilla similarly explained that the rebels claimed that all taxes on salt, alcohol and property had been abolished, and that provincial authorities' demands for those

\footnotetext{
18. Archivo General de la Nación (AGN), Pref. Ministerios Paquete 241 (Oficio 1329: September 14, 1923).

19. ARA, Pref. OSC leg. 18 (Oficio 129, September 27, 1923).

20. ARA, Pref. OSLM leg. 24 (Unnumbered oficio: July 18, 1923).

21. ARA, Pref. OSLM leg. 24 (Unnumbered oficio: July 30, 1925).

22. ARA, CSJ, leg. 407 , cuad. 1 , fol. 37.
} 
payments were thus wholly illegitimate. ${ }^{23}$ Guadalupe Martínez, a 40-year-old woman from Concepción, testified that the rebels proclaimed that the fiscal taxes had been abolished, and that Vila was killed for that reason: "he was robbing them, as said taxes did not exist." 24

The Llaccolla/Concepción case was far from unique; assertions about authorities' and agents' fraudulent collection of nonexistent taxes emerged with surprising frequency in rural Ayacucho during the 1920s. Over and over again, indigenous and nonindigenous men and women referenced the popular belief that various government levies were the arbitrary creations of corrupt local authorities and government agents, rather than official policies of the Leguía government. Such charges emerged, for example, in response to the Leguía government's fees for the registration of cattle brands. The lieutenant governor of Pampa Cangallo asserted that local indigenous residents aimed to take his life, that of the municipal agent, and of the subprefect, all because of the recent notification of the new cattle brands registry. "They believe that no such law exists," the lieutenant governor explained, adding that the rebels asserted that the authorities had created the registry in order to defraud local residents. ${ }^{25}$ Cangallo Subprefect Leóncio Cárdenas, in turn, asserted in 1924 that some participants in the "rebellion of Indians of the past year" were once again "propagating the falsehood that the supreme government has exempted the indigenous race from the vial law, [and] from the payment of contributions and other taxes." 26 Although the documentary record offers no explanation for the emergence of these unfounded rumors, the frequency of these accusations reveals campesinos' profound distrust of government officials.

As suggested in Subprefect Cárdenas's above comment, rumors also emerged that the Leguía government's most hated tax, the servicio de conscripción vial (highway conscription service), no longer existed. A tax paid not with money, but with labor service, the conscripción vial required all men aged 18 to 60 to provide between six and 12 days per year of unremunerated labor for highway construction. Yet although the law theoretically applied to all men, the lengthy list of exceptions and the ability to purchase service exemptions meant that in practice, the law applied only to indigenous men. ${ }^{27}$ Claims about the conscripción vial's

23. ARA, CSI, leg. 407 , cuad. 1, fol. 35 .

24. ARA, CSI, leg. 407 , cuad. 1 , fol. 36.

25. ARA, Pref. OSC leg. 18 (Unnumbered oficio: November 20, 1922)

26. ARA, Pref. OSC leg. 18 (Unnumbered oficio: June 10, 1924).

27. Thomas M. Davies, Indian Integration in Perw: A Half Century of Experience, 1900-1948 (Lincoln: University of Nebraska Press, 1970), pp. 82-86. Historian Nelson Pereyra Chávez offers a thoughtful consideration of the Conscripción Vial in Ayacucho, although he understates the scale of rural opposition to the forced labor service. Sec his work, "Los campesinos y la conscripción vial: Aproximaciones al estudio de las relaciones estado-indígenas y las relaciones de mercado en Ayacucho (1919-1930)," in Estado y mercado en la bistoria del Peru, Carlos Contreras and Manuel Glave, eds. (Lima: Pontificia Universidad Católica del Perú, 2002), pp. 334-350. 
abolition were particularly widespread in rural Ayacucho. Cangallo's subprefect reported in October 1924 that six indigenous subtenants of the Pomacocha hacienda had incited their neighbors to resist the highway construction work, "alleging that the law of highway service was only invented by the controlling tenant of that hacienda." 28 The lieutenant governor of Pampa Cangallo reported in October 1922 that he was unable to force any of the residents of his jurisdiction to partake in bridge-building work because of their marked opposition to the conscripción vial law. The lieutenant governor blamed their opposition on a rumor that the road conscription was not actually a law, but rather an invention of the lieutenant governor and the subprefect. ${ }^{29}$ Cangallo's subprefect made similar accusations against a local lawyer named Estanislao Amorín. According to the subprefect, Dr. Amorín filled Cangallo's rural indigenous population with "ideas of rebellion, making them believe that the law of highway conscription no longer exists and that, as such, they should not lend any services related to the highway." 30 And when the lieutenant governor of Cangallo district informed residents of the Huancarucma community that they were to attend their vial labors, residents refused to go, explaining that they had heard that the road labor law no longer existed and that the subprefect was "doing nothing more than abusing them in making them work." 31

Rounding out rumors of nonexistent taxes and labor service, stories spread in rural Ayacucho that the Leguía government had fallen. Talk circulated in La Mar province in mid-1925 that President Leguía had been arrested and imprisoned, while word also spread that Leguía's opponents had overthrown his government. ${ }^{32}$ These rumors of Leguía's downfall were, in turn, closely connected to the promise of an end to taxes. Huanta's subprefect warned in July 1924 that agitators from Puno were propagandizing among Ayacucho's indigenous peasants, denouncing the coca tax, the alcohol levy and the highway conscription service, "making them believe that a change of Government will make all of these taxes disappear." ${ }^{33}$ Similarly, a group of men from the Ayacucho province of Víctor Fajardo proclaimed that the fall of Leguía would mean "the disappearance of taxes, contributions, the conscripción vial, the cattle brand registry, military service and many others." 34 Put simply, Ayacuchano men and women equated Leguía's (supposed) ouster with an end to his government's fiscal policies.

28. ARA, Pref. OSC leg. 18 (Oficio 68: October 9, 1924).

29. ARA, Pref. OSC leg. 18 (Unnumbered oficio: October 12, 1922).

30. ARA, Pref. OSC leg. 19 (Oficio 89: November 25, 1926).

31. ARA, Pref. OSC leg. 19 (Unnumbered oficio: November 15,1926 ).

32. ARA, Pref. OSLM leg. 24, (Oficio 58: April 25, 1925).

33. ARA, Pref. OSH lcg. 13 (Oficio 108: July 17, 1924). 1924).

34. ARA, Pref. Oficios de la Subprefecture de Víctor Fajardo (OSVF) leg. 37 (Unnumbered oficio: September 9 , 
Choosing to believe-or, at least, spread-these rumors, indigenous men and women from rural Ayacucho were avoiding the payment of onerous taxes. Those taxes were indeed so burdensome that campesinos from across the department protested against the levies in many different ways, writing letters of protest to the president, visiting the offices of the Tax Collection Company to demand the taxes' repeal, and sending representatives to Lima to press for exemptions. ${ }^{35}$ Sometimes, as in the Vila murder, these protests led to, or at least threatened, violence. The departmental head of the Tax Collection Company, for instance, warned in August 1923 that "the lives of our employees are in imminent danger" because of indigenous uprisings in the province of La Mar, and he noted that the employee of the Tambo tax collection office had been forced to flee. ${ }^{36}$ Protests against the conscripción vial were just as frequent and as heated. ${ }^{37}$ By endorsing rumors about the nonexistence of these taxes or the downfall of the president who dictated them, Ayacucho's indigenous campesinos and their civilian colonels found a convenient reason to avoid paying those taxes, either with their money or their labor.

Rumors about corrupt authorities charging nonexistent taxes had an obvious appeal: if the taxes were fictitious, then no one would have to pay them. These rumors also had considerable credibility, as Ayacucho's political authorities were notoriously abusive and dishonest. Ayacucho authorities-ranging from district governors and mayors to provincial subprefects to departmental prefects-were the subject of frequent and bitter complaints from countless Ayacuchanos. Representing the residents of seven indigenous communities, an indigenous man named Cirilo Cárdenas presented a petition to the Cangallo subprefect in January 1924, complaining of "the abuses and arbitrary acts of the subaltern political authorities of this province, who force them to supply livestock and cattle for free for the sustenance of forces stationed in this region." 38 In another example, four indigenous men from the community of Chungui, La Mar, petitioned the Ayacucho prefect in July 1925. These men had been commissioned by their community to inform the prefect of the "series of humiliations, abuses and exactions" committed by the Chungui governor and his lieutenant governors. ${ }^{39}$ The men asserted that the prefect was the "only authority who can return us to tranquility, disciplining and punishing your subalterns, who do not carry out their functions and who have built their authority by lashing our race." ${ }^{40}$ Similarly, a number of

35. Proyecto Especial de Titulación de Tierras (PETT), Luricocha (January 4, 1925); ARA, Pref. OSH leg. 13 (Oficio 88: May 26, 1924); AGN, Ministerio del Interior (MI) leg. 248, subprefecturas (Oficio 31: June 2, 1924).

36. ARA, Pref. OCRI leg. 108 (Oficio 673: August 9, 1923). For other examples, see ARA, Pref. OCRI leg. 108 (Oficio 803: June 29, 1924; Oficio 673: August 9, 1923; Oficio 674: August 11, 1923).

37. ARA, Pref. OSH leg. 13 (Oficio 108: July 17, 1924); Pref. OSLM (Oficio 8: January 12, 1925); ARA, Pref. OSC leg. 18 (Unnumbered oficios: November 20, 1922, July 10, 1924).

38. ARA, Pref. Oficios recibidos de diferentes ministerios (ODM) leg. 65 (Oficio 11: January 3, 1924)

39. ARA, Pref. OSLM leg. 24 (Oficio 904: July 13, 1925).

40. Ibid. 
indigenous campesinos from Ccarhuahurán, Huanta, appeared before the Ayacucho Departmental Junta of the Patronato de la Raza Indigena (Guardianship of the Indian Race) in October 1928, asking for the removal of their district governor, Federico Ludeña, on the grounds of his many abuses. ${ }^{41}$

The substance of these complaints and charges varied from case to case. Accusations against authorities frequently included charges of unjust taxation. The lieutenant governor of Pampa Cangallo recalled that in May 1922, for instance, residents of his district had risen up against the subprefect, believing that the latter had a secret plan to make them register as tax payers in the Ayacucho prefecture. ${ }^{42}$ Rural Ayacuchanos also bemoaned their authorities' unjust labor exactions. A number of residents of Huambalpa, Cangallo filed a complaint against their governor, Octavio Baes, asserting that he forced indigenous campesinos to carry out private labors for him, building his home and working in his fields. ${ }^{43}$ Theft was an additional source of anger. These same Huambalpa residents charged that Governor Baes regularly collected livestock, eggs, chickens, and sheep from district peasants without remuneration, using a forthcoming official visit as his pretext. ${ }^{44}$ Others accused their authorities of stealing indigenous land. Members of the Putica community in Cangallo solicited the support of the Pro-Indian Rights Tawantinsuyo Committee to file a complaint against their two lieutenant governors who were trying to appropriate the titles to Putica's communal landholdings. ${ }^{45}$ The secretary general of the Tawantinsuyo Committee wrote the Ayacucho prefect on the Putica campesinos' behalf, asking that he "put an end to these outrages by persons who, aided by the post that they hold, have only denigrated the sacred principles that characterize political administration." 46 Given Ayacuchano authorities' established record of misdeeds, it was easy for indigenous men and women in Ayacucho's countryside to believe that these abusive authorities were corruptly levying taxes that simply did not exist.

Indigenous campesinos' anger at district, provincial and departmental authorities helps explain why they organized under civilian colonels. The civilian colonels were the only leaders whom Ayacucho campesinos were able to choose for themselves, given that they were disenfranchised by their assumed illiteracy and by a centralized political system where regional and local authorities were appointed rather than elected. Furthermore, the civilian colonels organized and led indigenous campesinos' protests against official authorities and their agents. Colonel

41. ARA, Pref. Oficios recibidos de diferentes instituciones (ORDI) leg. 111 (Oficio 117: October 22, 1928).

42. ARA, Pref. OSC leg. 18 (Unnumbered oficio: October 12, 1922). For other complaints about taxation, sec ARA, Pref. ORDI leg. 111 (Oficio 32: October 13, 1924).

43. ARA, Pref. OSC leg. 19 (Unnumbered oficio: August 4, 1926).

44. Ibid.

45. ARA, Pref. ODM leg. 65 (Unnumbered oficio: June 16, 1920).

46. ARA, Pref. ODM leg. 65 (Unnumbered oficio: May 5, 1924). 
Nieto, for example, headed Llaccolla and Concepción campesinos' protest against their abusive tax collector, Juan Pablo Vila. Importantly, Vila was not the only authority whom Colonel Nieto's protest denounced. Witnesses at Colonel Nieto's trial also referenced protesters' anger at a second authority: the national deputy for La Mar province, Albino Añaños. Faustino Huamaní, a 35-year-old indigenous man from Ocros, testified that Albino Añaños ordered the creation of new taxes in congress, and that Añaños's taxes triggered the uprising. ${ }^{47}$ Apolinario Méndez, in turn, testified that the rebels asserted that "Añaños, Deputy for La Mar, was the one responsible to the fiscal taxes," and that they killed Juan Pablo Vila for being an Añaños supporter. ${ }^{48}$

Albino Añaños was a national political authority and hacendado infamous for his abuses, especially in the province of La Mar. As an indigenous La Mar campesino named Damien Torres described it, "[f]or a long time, we Indian pueblos surrounding San Miguel, capital of La Mar, have been victims of the innumerable abuses of Deputy Añaños and his sons." 49 Those abuses led to an indigenous protest by La Mar campesinos in December 1922, along with a violent counterattack by local and regional authorities. As Torres described it, Deputy Añaños arranged for the Ayacucho prefect "to send gendarmes, abundant weapons, munitions, with instructions to kill Indians." As a result, the gendarmes-together with Añaños's thugs-attacked local indigenous campesinos, "shooting them without mercy" and leaving four dead, eight wounded, as well as burning campesino homes, taking their provisions, and rounding up cattle for food ${ }^{50}$ Damien Torres was not the only person to denounce Añaños's abuses. Middle-class Ayacucho lawyers, journalists and politicians also voiced sharp critiques against Añaños, conducting what the national deputy decried as a "hateful and unwarranted campaign against my person." 51

Añaños's abuses were notorious, but it seems peculiar that the Llaccolla and Concepción campesinos invoked him in their protest. As the representative for the province of La Mar, Albino Añaños had no jurisdiction over Llaccolla and Concepción peasants living in the neighboring province of Cangallo. Why, then, did these protesters so despise Añaños? One explanation is taxes. As both Faustino Huamaní and Apolinario Méndez explained, Llaccolla and Concepción campesinos believed Añaños responsible for the creation of new taxes. Albino Añaños himself made reference to this sort of charge against him. Addressing the Chamber of Deputies in 1924, Añanos explained that the July 1923 attacks on his

47. ARA, CSI, leg. 407, cuad. 1, fol. 20.

48. ARA, CSJ, leg. 407, cuad. 1, fol. 23.

49. AGN, MI, Camara de senadores (CS), leg. 231 (Telegram 31: December 20, 1922).

50. Ibid.

51. AGN, MI, Camara de dipurados (CD) leg. 249 (Oficio 79: January 8, 1924). 
property came "because I was considered the author of taxes on salt, alcohol, cbancaca [solidified sugar] etc."52 Añaños's popular reputation as the authority responsible for introducing illegitimate taxes trumped the finer mechanics of political jurisdiction, and he became a target of rural anger far outside the boundaries of La Mar province. Indigenous Ayacuchano men and women looked to their civilian colonels to organize and direct protests against abusive authorities like Añaños.

\section{Networks of Collaboration and Protest}

A second explanation for Llaccolla and Concepción peasants' anger toward Deputy Añaños rests with their considerable political connections across physical space. The indigenous men and women who seized Juan Pablo Vila in September 1923 marched him out of Cangallo province and into the La Mar community of Pampas. While no witness explained exactly why the protesters did so, a few noted the protesters' ties to rebel groups in Chilcas, La Mar. Félix Carras testified that once the Llaccolla and Concepción rebels reached Pampas, they "sent a note to the Chilcas ringleaders, asking if they could send the prisoner to them." ${ }^{25}$ Carras further explained that when the rebels received a negative reply, they killed Vila. Manuel Najarro offered similar testimony, explaining that "those montoneras had received a note from Chilcas, from the ringleaders, which said that they had no orders to receive prisoners." ${ }^{54}$ A man named Lorenzo Ccardia likewise testified that the Llaccolla and Concepción montoneras contacted the "Chilcas ringleader" with a note, receiving a negative answer in return. ${ }^{55}$

Ccardia's reference to the "Chilcas ringleader" suggests that Llaccolla and Concepción peasants had ties with a major political movement taking place inside $\mathrm{La}$ Mar. ${ }^{56}$ From the time of the December 1922 violence described above, La Mar was the site of several serious conflicts between indigenous peasants, Añaños supporters and military forces. In July 1923, for example, the La Mar tax collection office reported a four-hour armed combat that left two of Añaños's sons and six gendarmes dead. ${ }^{57}$ (Although it is highly unlikely that no indigenous peasants were wounded or killed in the conflict, the Tax Collection Company's telegram made no mention of indigenous casualties.) That same month, the governor of

52. AGN, MI, CD, leg. 249 (Unnumbered oficio: January 18, 1924).

53. ARA, CSJ, leg. 407 , cuad. 1, fol. 59.

54. ARA, CSI, leg. 407 , cuad. 1 , fol. 60 .

55. ARA, CSJ, leg. 407, cuad. 1, fol. 58.

56. Discussions of the events in La Mar appear in Kapsoli, Movimientos Campesinos, pp. 74-76; Eric Mayer, "State Policy and Community Conflict in Bolivia and Peru, 1900-1980" (PhD dissertation: University of California-Santa Barbara, 1995), pp. 277-315.

57. AGN, MI, Ministcrios, paq. 241 (Oficio 139: July 7, 1923). 
Chilcas reported that the indigenous residents of the community of Chilcas and several of its annexes attacked an Añaños hacienda on the orders of a colonel named Paulino Romero. ${ }^{58}$ So, when Llaccolla and Concepción campesinos corresponded with the "Chilcas ringleader," they were demonstrating a connection with a significant indigenous mobilization inside La Mar.

Llaccolla and Concepción campesinos were not the only indigenous Ayacuchanos with connections to political activists in La Mar during this period. Two indigenous men from the Cangallo district of Carhuanca, imprisoned on charges of sedition and rebellion in 1924, testified that they had traveled to La Mar to acquire the ProIndian Rights Tawantinsuyo Committee's declaration of principles. The lengthy document they procured, and later read to residents of several communities in and around Carhuanca district, made explicit reference to Paulino Romero, naming him a delegate of the Tawantinsuyo Committee.$^{59}$ Cangallo Subprefect Leóncio Cárdenas, in turn, warned that an indigenous mobilization in the district of Huambalpa was instigated in part by the "ringleaders of the La Mar movement."

Just as Llaccolla and Concepción protesters had political connections that stretched northward into La Mar province, they also had strong political ties reaching eastward toward the district of Pampa Cangallo. They were closely connected to a political leader from Pampa Cangallo known as Colonel Juan de Dios Alarcón. Faustino Huamani explained at the Vila murder trial that the Llaccolla and Concepción campesinos "had risen up at the insistence of Juan de Dios Alarcón, leader of the 'Morochuco' montonera." Simeon Cárdenas explained that "the montonera was in agreement with those from Pampa Cangallo. They read some papers that stated that said contributions had been abolished." 62

Juan de Dios Alarcón was arguably the most prominent of the civilian colonels organizing in oncenio-era Ayacucho. Alarcón described himself as an indigenous man from Cangallo province in a 1924 petition to President Leguía, and the errors of spelling, word choice and grammar that characterize the letters he penned suggest only minimal education and/or that Spanish was not his first language. ${ }^{63}$ Alarcón was likely a resident of the Cangallo district of Pampa Cangallo.

58. ARA, Pref. OSLM leg. 24 (Unnumbered oficio: July 18, 1923). In "State Policy and Community Conflict," p. 278, Eric Mayer describes Paulino Romero as a middle-class lawyer, but I have found various documents that label Romero an indigenous peasant. See AGN, MI, Particulares, leg. 250 (Unnumbered oficio: January 31, 1924); ARA, CSJ, leg. 409 , cuad. 5 .

59. ARA, CSJ, leg. 409 , cuad. 5

60. Archivo Histórico Militar (AHM), libro c-296, fol. 304.

61. ARA, CSJ, leg. 407, cuad. 1, fol. 20.

62. ARA, CSJ, leg. 407, cuad. I, fol. 37.

63. ARA, Pref. OSC leg. 18 (Unnumbered oficios: August 27, 1922, September 5, 1922). 
He referred to himself as "Colonel of the Pampa" and his opponents often deemed him the "Colonel of the Morochucos," using the label regularly given to indigenous residents of Pampa Cangallo. Calling Alarcón "Colonel of the Morochucos" was a way to "Indianize" his identity and actions, for the label Morochucos conveyed Pampa Cangallo residents' racialized reputation as particularly subversive and prone to rebellion, much like the so-called "Iquichanos" whom Cecilia Méndez has studied ${ }^{64}$ As Subprefect Cárdenas phrased it, Pampa Cangallo residents had been "known by the generic name of 'Morochucos' since the Colonial epoch," and that they "have distinguished themselves with their rebellious and subversive spirit. They recognize no laws or authorities other than brute force." 65

While there is no evidence to suggest that Alarcón had formal military training, he readily used the title of colonel. He signed letters with the name "Juan D. Alarcón, Colonel," and wrote the words, "From the Colonel of Pampa Cangallo" upon one of his envelopes. ${ }^{66}$ And while Alarcón held no formal position of authority inside the province of Cangallo, he engaged other provincial authorities as an equal. He wrote, for example, letters to the governors of Chuschi and Quispillacta to express his urgent concerns about new tax requirements. ${ }^{67}$ It appears that the bulk of Colonel Alarcón's political activity involved holding meetings to protest government policies. Cangallo Subprefect Leóncio Cárdenas reported in September 1923 that Chuschi's governor had received instructions from "the ringleader of the rebels, Juan de Dios Alarcón" and had thus instructed "the Indians of his jurisdiction" to attend "the meeting of the rebels in Pampa Cangallo."68 Other reports about Alarcón's meetings came from a variety of sources. An indigenous man named Ambrosio Ramos, himself accused of being "one of the rebelling ringleaders" under Alarcón's command, testified that while he had not gone to any of Alarcón's meetings, he had heard about them. ${ }^{69}$

Llaccolla and Concepción campesinos were hardly the only Ayacucho peasants with ties to Colonel Alarcón. From late 1922 through 1923, authorities from throughout the province of Cangallo reported Alarcón's involvement with local indigenous men and women. In November 1922, for example, the lieutenant governor of Pampa Cangallo district relayed that he and the municipal agent had

64. Cecilia Méndez, "The Power of Naming, or the Construction of Ethnic and National Identities in Peru: Myth, History and the Iquichanos," Past and Present 171 (May 2001), pp. 127-160. My term "Indianize" borrows from de la Cadena, Indigenous Mestizos, pp. 6-7.

65. ARA, Pref. OSC leg. 18 (Oficio 66: November 22, 1922).

66. ARA, Pref. OSC leg. 18 (Unnumbered oficio: September 5, 1922).

67. ARA, Pref. OSC leg. 18 (Unnumbered oficios: August 27, 1922, September 5, 1922).

68. ARA, Pref. OSC leg. 18 (Oficio 129: September 27, 1923).

69. ARA, CSJ, leg. 409 , cuad. 21 , fol. 3. 
suffered a surprise attack by a considerable number of indigenous men and women from the communities of Uriguana, Huahuapucyo, Huancarucma, Pantin and Incaraccay. The lieutenant governor asserted that his attackers acted on the instructions of their leader, "the noxious element deemed colonel of this pueblo, Juan de Dios Alarcón." ${ }^{70}$ The governor of Totos alleged in December 1922 that a resident of his jurisdiction "negotiated secret agreements with the so-called Colonel of the Pampa, Juan de Dios Alarcón," developing plans to invade the provincial capital of Cangallo. ${ }^{71}$

Similar reports continued well into 1923. Cangallo Subprefect Leóncio Cárdenas sent an urgent telegram to the minister of war in August 1923, informing him that the "Indian uprising" in the district of Huambalpa was continuing, instigated by "Colonel Morochucos" and the leaders of the La Mar mobilizations. The subprefect warned that the rebels were threatening to invade the communities of Vilcashuamán and Carhuanca, and he asked for reinforcements to help capture "Colonel Morochucos, tenacious agitator of the public order."72 Cangallo's examining magistrate informed the Ministry of Justice in August 1923 that the indigenous residents of Sachabamba, Pallccacancla, Accomaco, Incaraccay, Pantin, Tanquehua, Pitica, and Huancaruyma were conducting military exercises under the leadership of "Colonel Morochuchos" with the aim of a looming invasion of the provincial capital of Cangallo. ${ }^{73}$ Affiliations with Alarcón were indeed so common that Subprefect Leóncio Cárdenas asserted that "Paras has been one of the few pueblos of this province to have proven indifferent to the call of the 'Morochucos' for an uprising in the month of last December."

Claims about Colonel Alarcón's political connections even extended into the urban realm. Pampa Cangallo's lieutenant governor reported in December 1922 that Alarcón had close informants who regularly traveled to urban Ayacucho and reported back about events in the city. The lieutenant governor also claimed that Alarcón himself traveled to the urban Ayacucho neighborhood of Carmen Alto in the immediate aftermath of a major antitax protest there. Alarcón and his informants made these trips, the lieutenant governor explained, because they were considering an invasion of the city. ${ }^{75}$ The governor of Chiara, a district in the province of Huamanga, likewise claimed a connection between Alarcón and urban Ayacucho. The governor asserted that his community was threatened "by the district of Carmen Alto and united with that of Pampa Cangallo," as activists from the latter

70. ARA, Pref. OSC leg. 18 (Unnumbered oficio: November 20, 1922).

71. ARA, Pref. OSC leg. 18 (Unnumbered oficio: December 6, 1922).

72. AHM, libro c-296, fol. 304.

73. AGN, MI, Ministerios, leg. 241 (Oficio 466: August 31, 1923).

74. ARA, Pref. OSC leg. 18 (Unnumbered oficio: January 27, 1923)

75. ARA, Pref. OSC leg. 18 (Unnumbered oficio: December 13, 1922). 
two areas wanted to enter Chiara. The governor even claimed that "these badtempered rebels" had threatened his life. ${ }^{76}$ While many of these reports of Colonel Alarcón's activities and plans were probably exaggerated or even fabricated, the frequency of claims about Alarcón, and the fact that some of those claims came from humble indigenous peasants rather than authorities, suggest that Alarcón was indeed connected to a broad range of political activities in rural and urban Ayacucho. The reach of the civilian colonels was, then, incredibly long.

Taken together, the above examples reveal a broad web of indigenous cooperation and consultation that stretched far beyond the confines of individual communities. Hardly localized, isolated political actors, civilian colonels and their followers collaborated with indigenous men and women living in other Ayacucho districts and provinces, and occasionally with urban residents. But while this indigenous political web is readily apparent in the archival record, its origins remain unclear. We can only speculate as to how indigenous men and women living so far apart from one another developed their impressive political network. The likeliest explanation involves campesinos' participation in the national meetings of the Comité Pro-Derecho Indígena Tawantinsuyo. Indigenous men, and some women, from across Ayacucho traveled to Lima to participate in the meetings of the Tawantinsuyo Committee, and at those meetings they would have encountered indigenous activists from Ayacucho communities distant from their own. Those encounters probably formed the basis for the network of political cooperation and collaboration that emerged inside rural Ayacucho. Certainly, both Colonel Juan de Dios Alarcón and Colonel Paulino Romero had connections to the Tawantinsuyo Committee, as did the Carhuanca peasants who traveled to La Mar to acquire their edict. But whatever its basis, the political network of Ayacucho's indigenous peasants was impressive in both size and strength.

On occasion, Ayacucho campesinos' oncenio-era political connections stretched further still, crossing the boundaries of class divides. Many Ayacucho hacendados shared campesinos' antipathy to the Leguía government's taxation and labor laws, and many landlords proved staunch opponents of Leguía's policies and of Leguía himself. Hacendado opposition to Leguía was not unusual in the Peruvian context. As historian Marta Irurozqui reminds us, Peru's elites were deeply and often bitterly divided during the 1920s. ${ }^{77}$ Inside Ayacucho, hacendado opposition to Leguía was rooted in economics. Many rural landlords believed that the Leguía

76. ARA, Pref. Oficios recibidos de diferentes gobernaturas distritales (OGD) leg. 40 (Unnumbered oficio: December 6, 1922).

77. Marta Irurozqui, "El Perú de Leguía: Derroteros y extravíos historiográficos," Apuntes 34 (Primer Semestre 1994), p. 86. Irurozqui's article critiques historiographical discussions of oncenio-era elites, arguing that scholars have too often substituted ideological agendas for careful historical analysis.

78. ARA, Pref. OCRI, lcg. 108 (Oficio 644: May 25, 1923). 
government's taxes on alcohol and coca would grossly restrict the profits they made from those goods. An employee of the Tax Collection Company wrote the Ayacucho prefect in May 1923, requesting police accompaniment for collection of the alcohol tax in Cangallo, due to the "hostile character of resistance of the producers of this valley." 78 This same employee ultimately resigned from his position, blaming "the lack of guarantees for the exercise of his post, the fact that his life was threatened, and that he was mocked by the hacendados of this region." 79 Within the province of Huanta, provincial authorities singled out nearly a dozen hacendados who actively opposed the Leguía government's levies on coca and alcohol. ${ }^{80}$

A number of Ayacucho landlords also staunchly opposed the conscripción vial law. That service took much-needed indigenous peasant laborers off of their hacienda lands, leading many hacendados to challenge the law. ${ }^{81}$ Within Huanta, the same hacendados who voiced opposition to the coca and alcohol levies protested against the conscripción vial. ${ }^{82}$ Across Ayacucho, in turn, many departmental hacendados who were not otherwise active opponents of the Leguía regime opposed the conscripción vial, most likely because they wanted their hacienda workers laboring on their land, not on distant road projects. The owner of the Airabamba hacienda, in Vischongo, Cangallo, blocked 50 of her hacienda workers from carrying out their vial service in 1928 , asserting that the law had been suspended. ${ }^{83}$ Similarly, Nicanor Carrasco, owner of the Virán hacienda in Carhuanca, Cangallo, urged campesinos from the adjacent community of Ocopa to abstain from their vial duties. ${ }^{84}$ When a military sergeant traveled to Ocopa in July 1929 to notify indigenous peasants of their upcoming labor duties, he found Ocopa homes empty. The sergeant then headed to the nearby Hacienda Virán. There, the sergeant spoke with hacendado Nicanor Carrasco, who asserted "in an energetic and hostile form" that so long as he had no direct order from the prefect, he would not send his people to the vial labor. ${ }^{85}$

Shared peasant-hacendado opposition to the Leguía government's taxes and labor laws resulted in some unusual political partnerships in the department. The Ayacucho head of the Tax Collection Company asserted in October 1923 that Cangallo hacendados "hypocritically keep the Indians of the surrounding pueblos

79. ARA, Prcf. OCRI, leg. 108 (Oficio 709: October 1, 1923). 1924)

80. ARA, Pref. OSH, leg. 13 (Unnumbered oficios: January 24, 1924, October 14, 1923; Oficio 88: May 26,

81. ARA, Pref. Oficios Recibidos de Conccjos Provinciales (ORCP) (Oficio 432: October 14, 1921). Nelson Pereyra likewise notes opposition to the Conscripción Vial among Ayacucho hacendados. See, "Los campesinos y la conscripción vial," p. 345.

82. ARA, Pref. OSH, leg. 13 (Unnumbered oficio: January 21, 1924).

83. ARA, Pref. OSC leg. 19 (Unnumbered oficio: August 6, 1928).

84. ARA, Subprefectura Cangallo (SC), Caja 23 (Oficios de Carhuanca [OC]; July 21, 1929).

85. ARA, SC, Caja 23 (OC: July 8, 1929). 
stirred up" in order to challenge the levy on alcohol. ${ }^{86}$ Joint protests by indigenous peasants and hacendados proved especially pronounced in the province of Huanta. The district mayor of Huanta's Luricocha district complained that a number of prominent local landlords, including Apolinario Fajardo, Aristides Flores and Hilario Medina were "making propaganda among the Indian masses about the coca tax, provoking a general uprising against the stability of order" in November 1924. ${ }^{87}$ Huanta's subprefect complained in May 1924 that the hacendado Max Gil- "known agitator of the Indian masses"-was traversing local communities, inciting campesinos to demand the repeal of the new tax on the coca leaf. ${ }^{88}$ In another example, a soldier stationed in Huanta reported that a large protest against the coca tax had taken place in October 1923. According to the soldier, the protest had turned violent on the prompting of over half-a-dozen Huanta hacendados, who urged the primarily peasant protesters to throw stones at the soldiers observing the demonstration. ${ }^{89}$ Huanta authorities similarly complained that provincial landlords were publicly inciting indigenous peasants to resist their road-building labors. ${ }^{90}$

There were, of course, sharp limits on these campesino-hacendado partnerships. Throughout much of rural Ayacucho, campesinos and hacendados fought bitterly over land rights, each claiming the ownership of the same rural properties. A particularly heated land conflict emerged between National Deputy Albino Añaños and the indigenous men and women who lived on and around the properties that Añaños deemed his own. Albino Añaños complained in the Chamber of Deputies in January 1924 of the charges levied against him in La Mar newspapers. He stated, "Among the claims they make against me, they say: that I am a gamonal [abusive rural strongman] who has snatched the holdings of indigenous communities." 91 There were also other, less prominent, struggles over property fought between indigenous peasants and the hacendados who held their land. ${ }^{92}$ These land conflicts all placed definite limits on the extent of campesino-hacendado political collaboration in the 1920 s.

For our purposes here, however, the most significant limitation on these partnerships across lines of class involves the colonels. Where there were indigenous colonels leading the protests, hacendados failed to join. Although hacendado opposition to the Leguía regime's policies was often substantial, no Ayacucho

86. ARA, Pref. OCRI, leg. 108 (Oficio 709: October 11, 1923).

87. ARA, Pref. OSH, leg. 13 (Unnumbered oficio: January 24, 1924).

88. ARA, Pref. OSH, leg. 13 (Oficio 88: May 26, 1924).

89. ARA, Pref. OSH, leg. 13 (Unnumbered oficio: October 14, 1923).

90. ARA, Pref. OSH, leg. 13 (Unnumbered oficio: January 21, 1924; Oficio 20: January 24, 1924).

91. AGN, MI, CD, leg. 249 (Oficio 79: January 8, 1924).

92. AGN, Ministerio de Trabajo, 3.13.2.1 (Fol. 9: September 26, 1930). 
hacendado joined together with the civilian colonels leading indigenous protests in the department. Ayacucho's hacendados seemed willing to ally with indigenous campesinos only when they were certain of their own leadership. While there is no documentary evidence to explain hacendados' choices, it seems likely that these men were unwilling to subordinate themselves to the leadership of civilian colonels whom they viewed as their race and class inferiors. Indeed, as we will see in the closing pages of this article, Ayacuchano hacendados, together with government authorities, often cast the protests under civilian colonels as dangerous acts of "race war." Elite Ayacuchanos" unwillingness to collaborate with the department's civilian colonels placed sharp limits on the extent, and ultimately the strength, of rural indigenous peasants' political web.

\section{The Mrlitarization of Indigenous Protest}

Rural Ayacucho's civilian colonels led protests driven by anger at abusive authorities and characterized by connections across space. Testimonies about Colonel Juan Nieto's protest also reveal considerable popular militarism, along with official efforts to squash that militarism. If we understand militarism as the adoption of soldierly practices and principles, then popular militarism was evident in the Llaccolla/Concepción protests, and in many of the rural political efforts undertaken in 1920s Ayacucho. The same was true across much of Peru. Steven Pent has demonstrated that participants in the Comite Pro-Derecho Indígena Tawantinsuyo, an expressly civilian organization, brought a martial air to many of their actions, marching in formation to demand indigenous rights and bringing a military-like discipline to the Tawantinsuyo Committee. ${ }^{93}$

Popular militarism in rural Ayacucho found clear expression in the leadership of civilian colonels. Llaccolla and Concepción campesinos affiliated themselves with Colonel Juan Nieto and Colonel Juan de Dios Alarcón, but these leaders were only two of several indigenous Ayacuchanos who assumed the title of colonel during Leguía's oncenio. Reports of indigenous campesinos' use of the title colonel surfaced in other areas, too. Cangallo Subprefect Leóncio Cárdenas referenced a man named Félix Gutiérrez, explaining that he "took the title Colonel of Chito in the last uprising." 94 In addition, the governor of Chilcas asserted in July 1923 that local indigenous peasants had received a secret communication from "Pablo or Paulino Romero, colonel," who ordered them to march on a nearby hacienda. ${ }^{95}$ Although many of these leaders had likely performed their

93. Pent attributes this militarism to the presence of licenciados (men who have completed their compulsory military service) in the Committee. See "Bridging the Urban-Rural Divide," pp. 113, 116.

94. AGN, MI, Subprefecturas, leg. 248 (Oficio 31: June 2, 1924).

95. ARA, Pref. OSLM, leg. 24 (Unnumbered oficio: July 18, 1923). 
obligatory military service, required in Peru since 1912, none appeared to have had a continuing affiliation with Peru's armed forces. ${ }^{96}$

In taking the title of colonel, Alarcón, Nieto, Romero and others like them were laying claim to a very specific form of political authority: military authority. Choosing military authority, indigenous colonels and their followers were indirectly rejecting traditional forms of indigenous authority like the varayoc or the cacique. Those forms of authority were simply not viable options at this historical juncture. Early in his presidency, Leguía outlawed varayoc service, and that prohibition of service by these indigenous authorities, holders of the staff of authority, cost the office some of its power and prestige. ${ }^{97}$ Choosing the label of colonel also reflected the political reality that military and civilian forms of authority regularly overlapped in this period of Peruvian history. As historian Cecilia Méndez explains, the explicit divide between civil society and the military found in contemporary Peru is a recent phenomenon, emerging as a product of the professionalization of the military over the course of the twentieth century. During the nineteenth and early twentieth centuries, in contrast, military and civilian authority often fused. ${ }^{98}$ The presidency of war hero General Andrés Avelino Cáceres is just one obvious example. As such, a military title like colonel carried implicit political authority. There were also significant historical precedents for the popular application of military titles to rural Andean leaders. Historian Sinclair Thomson notes that indigenous leaders in a 1771 protest in Chulumani assumed honorific military titles like "general" to legitimize their leadership and prove their readiness for self-government. ${ }^{99}$ In the context of 1920 s Ayacucho, then, choosing the title colonel made solid historical sense.

Importantly, indigenous men and women in rural Ayacucho imbued their politics with military content in numerous other ways. One example occurs with the protesters' moniker; many witnesses labeled the mobilized campesinos montoneras. Víctor Oré, a merchant residing in Concepción, spoke of the "horrendous exploits by the montoneras." 100 Jesusa Martínez likewise discussed the "montonera from Llaccolla." 101 The term montoneras not only implied militarized soldiers, it also harkened back to the efforts of the indigenous peasants who fought Chilean forces in the War of the Pacific, peasants typically labeled monton-

96. On obligatory military service, see Frederick M. Nunn, "Professional Militarism in Twentieth-Century Peru: Historical and Theorctical Background to the Golpe de Estado of 1968," Hispanic American Historical Review 59:3 (August 1979), p. 402.

97. Davies, Indian Integration, p. 72.

98. Méndez, "Las paradojas del autoritarismo," pp. 18-20.

99. Sinclair Thomson, "We Alone Will Rule. . ': Recovering the Range of Anticolonial Projects among Andean Peasants (La Paz, 1740s-1781)," Colonial Latin American Review 8:2 (1999), p. 283.

100. ARA, CSJ lcg. 407, cuad. 1, fol. 2.

101. ARA, CSJ leg. 407, cuad. 1, fol.11. 
eras. ${ }^{102}$ Widespread use of the term "montoneras" in oncenio-era Ayacucho can likewise be seen in a complaint from the governor of the Cangallo community of Chiquintirca. The governor informed the Ayacucho prefect that "it is completely false for us to be described as montoneras. That has been the idea of the rebel Braulio E. Zúniga who, as head of the montonera, has been compromising all the communities of the surrounding pueblos with his farces." 103 This governor wanted to distance himself and his community from association with militarized campesinos, likely fearing the possibility of state repression.

The militarized cast of rural indigenous mobilization under civilian colonels also included forced conscription. Faustino Huamani, for example, testified that "Indians rose up in' fear of Alarcón's threats," including a threat to burn the pueblos of those who opposed the Vila punishment. ${ }^{104}$ A Concepción man named Simeon Cárdenas similarly testified that the montoneras forced community residents to join in the protest under Colonel Nieto, threatening to sack and burn their homes if they did not participate. ${ }^{105}$ Certainly, some witnesses utilized claims of coercion to mitigate their own guilt. Apolinario Méndez testified that he was drawn into the uprising because two of his Llaccolla neighbors threatened to burn down his house if he abstained. Méndez also testified that the rebels forced him to carry a pellet shotgun and compelled him to fire it at the (already deceased) Juan Pablo Vila. Méndez relayed that he complied for fear of being killed himself. ${ }^{106}$ Testimony about forced participation, however, was not exclusively exculpatory; even individuals who did not join the indigenous mobilizations testified about coerced involvement. In July 1923, the governor of Chilcas asserted that the indigenous residents of the community of Chilcas and its annexes Escana, Pampas, Rumirumi, and Retama acted on orders from Colonel Paulino Romero who threatened to burn their towns if they did not march on an Añaños hacienda. The Governor explained that Chilcas residents had followed Romero's instructions and his "sinister plans" only out of fear. ${ }^{107}$ Militarized indigenous protest, then, included decidedly unromantic practices like coercion and intimidation.

Crucially, the militarization of rural indigenous protest did not automatically entail campesinos' use of violence. Paulino Romero, for example, took the title of colonel and led mobilizations in La Mar, but he also served as an elected delegate of the strictly peaceful Pro-Indian Rights Tawantinsuyo Committee. Colonel Juan de Dios Alarcón-a man who assumed a military title and had connections with

102. See Mallon, Peasant and Nation.

103. ARA, Pref. OSLM leg. 24 (Unnumbered oficio: August 13, 1923).

104. ARA, CSJ, leg. 407, cuad. 1, fol. 20.

105. ARA, CSJ, leg. 407 , cuad. 1, fol. 37.

106. ARA, CSJ, leg. 407, cuad. 1, fol. 22.

107. ARA, Pref. OSLM leg. 24 (Unnumbered oficio: July 18, 1923). 
mobilized indigenous peasants throughout Cangallo province-also readily engaged in peaceful political activities, writing letters and holding meetings. There is also no compelling evidence to suggest that Colonel Alarcón himself perpetrated any acts of political violence, although many accused him of ordering bloody actions. Adopting soldierly forms and principles thus did not necessarily imply direct participation in violence.

Ayacucho and Peruvian government officials, however, failed to appreciate such distinctions and worked to stamp out all militarized organization by campesinos, violent or otherwise. Responding to uprisings, reports of uprisings, and reports of threatened uprisings, the Leguia government dispatched Infantry Battalion Number Seven to La Mar in mid-1923. ${ }^{108}$ From there, the battalion traveled to Cangallo, conducting a repression that Subprefect Leóncio Cárdenas described as a "pacifying labor." 109 That battalion not only used violence to quell indigenous protests, its members also seized livestock and foodstuffs from indigenous communities for their own subsistence, providing no remuneration to the rural men and women whose produce they took. ${ }^{110}$

Regional authorities also carried out waves of arrests, targeting all of those men-and they were exclusively male-whom they singled out as ringleaders. Colonel Nieto was arrested and tried for his role in the Vila murder, as were Faustino Huamaní and several others. ${ }^{111}$ Colonels Juan de Dios Alarcón and Paulino Romero were likewise arrested, along with over a dozen other indigenous men from the provinces of La Mar and Cangallo. Although many of those arrested won release from prison within the space of a year, their ensuing freedom was sharply limited. A January 1924 letter to President Augusto B. Leguía shows as much. That month, Colonel Alarcón, Romero and 13 other selfdefined indigenous men from the provinces of La Mar and Cangallo had the Tawantinsuyo Committee write a letter on their behalf, requesting government funds for travel between Lima and Ayacucho. The letter explained that the men had been sent to Lima as prisoners, "for the supposed crime of rebellion," but they had been released on the first of January, 1924. The men stated, "despite our desire and efforts to return to our respective homes, it has been impossible for us to get resources to that end." The men further explained that "we are presenting this request via the 'Tahuantinsuyo' Central Indian Committee, which is familiar with our state of misery."112

108. ARA, Pref. OCRI leg. 108 (Oficio 674: August 11, 1923); AHM, c-296 (Oficio 1614: July 12, 1923).

109. ARA, Pref. OSC leg. 18 (Unnumbered oficio: November 16, 1923).

110. ARA, Pref. OSC leg. 18 (Unnumbered oficios: May 9, 1924, November 15, 1926).

111. ARA, CSJ, leg. 407 , cuad. 1, passim.

112. AGN, MI, Particulares, leg. 250 (Unnumbered oficio: January 31, 1924). 
Release from prison, however, did not entail an end to harassment by departmental authorities. Faustino Ortiz, a La Mar member of the Pro-Indian Rights Tawantinsuyo Committee, petitioned the Ministry of Public Works in April 1924, asserting that some of the 17 indigenous men arrested as ringleaders in the "supposed Indian uprisings" met only continued pursuit from authorities once they were released from prison. Ortiz thus asked for action on their behalf. ${ }^{113}$ That action was not forthcoming. Cangallo Subprefect Leóncio Cárdenas dismissed Ortiz's assertions, stating that all those who had been arrested and released "have received ample guarantees from my office." Belying his claims of support, Subprefect Cárdenas then added that some of those individuals had "returned with the same disruptive ideas," and were once again spreading lies against the Leguía government. ${ }^{114}$

Departmental authorities and their civilian allies confronted campesino militarism in one additional way: they raised the specter of race war, twisting their descriptions of rural protests into racist depictions of Indian savagery. These inflammatory statements were not unusual in the Ayacucho context of the 1920s. National Deputy Albino Añaños complained that members of the Pro-Indian Rights Tawantinsuyo Committee were fomenting "racial rebellion of aboriginals against the white." 115 Nivardo Añaños, son of the national deputy, informed La Mar's Subprefect in April 1925 that indigenous men and women from the district of Anco had received a decree for the extermination of whites. ${ }^{116}$ The departmental head of the Tax Collection Company in La Mar, in turn, spoke in 1923 of the "rebellious spirit of these peoples, full of rancor and near ferocity against the people they accuse." 117 And in one final example, the La Mar subprefect reported in July 1925 that he had carried out an arms roundup in Chungui, as firearms "in the hands of Indians are too dangerous a threat to the stability of public peace." 118

Nonindigenous observers' turn toward tropes of Indian savagery was particularly transparent in discussions of the Vila murder. Subprefect Leóncio Cárdenas, for example, asserted that Vila's captors treated him with "inane inhumanity," torturing him for several days before killing him. ${ }^{119}$ Guillermo Quintanilla, a literate man originally from urban Ayacucho, testified that the rebels had cut off Pablo Vila's ears and then mutilated his hands. ${ }^{120}$ Tax Collection Company employee Carlos Byrne, in turn, reported that Vila had been forced to march barefoot, that

113. ARA, Pref. ODM leg. 65 (Oficio 99: April 24, 1924).

114. ARA, Pref. OSC lcg. 18 (Unnumbered oficio: June 10, 1924).

115. AGN, MI, CD, leg. 249 (Oficio 79: January 8, 1924).

116. ARA, Pref. OSLM leg. 24 (Oficio 51: April 17, 1925).

117. ARA, Pref. OCRI leg. 108 (Oficio 673: August 9, 1923).

118. ARA, Pref. OSLM leg. 24 (Unnumbered oficio: July 22, 1925).

119. ARA, CSJ, leg. 407 , cuad. 1, fol. 8.

120. ARA, CSJ, leg. 407 , cuad. 1, fol. 34-35. 
his ears had been cut off, and that he was murdered by decapitation. ${ }^{121}$ The autopsy report, however, made no mention whatsoever of missing ears, wounded hands, decapitation, or injuries beyond two gunshot wounds. ${ }^{122}$

One sad irony of the government's efforts to repress popular mobilization in the countryside was that the Leguía regime also took pointed steps to deny indigenous men and women the one resource without which their peaceful, nonviolent political efforts simply could not flourish: money. The Leguía government jealously guarded its monopoly on the right to tax, denying indigenous men and women the right to gather funds for their protection and advance, funds popularly known as the rama. Official complaints about the rama emerged as early as 1921. The Leguía government passed a Supreme Resolution in 1921, asserting that indigenous men and women in Puno were being forced to pay "a tax called the "rama" and that because said tax "is not approved by any law, decree or resolution" it therefore constituted an "anti-constitutional exaction." The law also urged authorities throughout the Republic to ensure that no one charged the rama inside their territories. ${ }^{123}$ The rama did not, however, quickly disappear. In 1924, Cangallo Subprefect Leóncio Cárdenas complained that the "Indian ringleader" Pablo Quicaño had collected rama payments from Putica residents to offset the cost of a trip to Lima, where he submitted claims for the community's defense. Subprefect Cárdenas relayed that he had suspended those rama payments, "as they have no reason to exist," and informed Quicaño to cease the collection. ${ }^{124}$ La Mar's subprefect, in turn, described the indigenous man Mariano Lagos as an "unscrupulous exploiter of his race, gathering together money under the title of rama, accused as a principal ringleader." The subprefect also relayed that Lagos was now in custody, jailed for collecting the unauthorized tax. ${ }^{125}$ Without money to fight for their rights in the courts or to fund trips to Lima to press for justice before national authorities, many indigenous men and women were often left with few options other than militarized violence to protest against abusive authorities and policies.

\section{Conclusions}

The time of the civilian colonels was not a long one. By 1926, the indigenous men popularly deemed colonels were essentially gone from the written historical record. The combination of military violence, arrests, and generalized repression had made

121. ARA, Pref. OCRI leg. 108 (Oficio 690: September 20, 1923).

122. ARA, CSJ, leg. 407 , cuad. 1 , fol. 90.

123. ARA, Pref.Oficios recibidos de la Dirección de Gobierno (ODG) leg. 95 (Unnumbered oficio: March 25, 1921).

124. AGN, MI, Subprefecturas, leg. 248 (Oficio 31 : June 2, 1924).

125. ARA, Pref. OSLM leg. 24 (Unnumbered oficio: August 9, 1926). 
continued mobilization by the colonels and their supporters impractical, perhaps even impossible. For the first years of the 1920s, however, Ayacucho's colonels and their followers operated inside a broad and complex political network, crossing district, provincial and rural/urban boundaries to forge a tight web of political collaboration and action. The colonels and their supporters combined violent action and peaceful political tactics to fight abusive government officials and agents who robbed, cheated, and mistreated indigenous campesinos. Mobilizing under civilian colonels, rural Ayacuchanos adopted many of the forms and features of military organization and action. Yet these same men and women also wrote letters of protest, utilized the court system, attended political meetings, and visited the offices of government officials. Their political actions were neither exclusively violent nor strictly peaceful; their methods instead fused violence and nonviolence.

Ayacucho's civilian colonels and the indigenous campesinos whom they led prioritized justice, using a broad range of tactics to protest against corrupt and abusive political authorities and government agents. Indigenous men and women's overarching desire for moral and just politics challenges arguments put forth in recent writings about the primacy of modernity discourses in oncenio-era Peru. ${ }^{126}$ While Ayacucho's pro-Leguía authorities did indeed speak at length about progress and advancement, echoing the rhetoric of the Peruvian president, their words found little resonance in the countryside. ${ }^{127}$ Indigenous men and women in rural areas typically eschewed talk of modernization and development, focusing on the far more pressing issues of political corruption and dishonesty. Inside Ayacucho, then, concrete concerns for justice far outweighed a longing for the nebulous ideal of modernity.

Although civilian colonels disappeared from Ayacucho's archival record by the latter years of the 1920s, their concerns and their forms of protest endured. Rural Ayacuchano anger at - and opposition to-abusive authorities continued across subsequent decades, for many of the same reasons considered in this article. ${ }^{128}$ Nor did popular militarism wholly disappear. Indeed, we can see the 1920 s mobilizations under civilian colonels as an important precursor of the rondas campesinas (armed peasant patrols) that emerged to battle against militants of the Peruvian Communist Party-Shining Path in the 1980 s and 1990s. ${ }^{129}$ Like the

126. Recent works stressing modernity include Willie Hiatt, "Flying 'Cholo': Incas, Airplanes, and the Construction of Andean Modernity in 1920s Cuzco, Peru," The Americas 63:3 (January, 2007), pp. 327-358; and Thomas Krüggeler, "Indians, Workers, and the Arrival of 'Modernity': Cuzco, Peru (1895-1924)," The Americas 56:2 (October 1999), pp. 161-189.

127. For an example, see ARA, Pref. OSC leg. 19 (Unnumbered oficio: November 17, 1926).

128. I explore rural Ayacuchano anger toward abusive authorities across the twentieth century in Hcilman, "By Other Means,"

129. For an introduction to the rondas campesinas, see Mario Fumerton, From Victims to Heroes: Peasant Counter-rebellion and Civil War in Ayacucho, Peru, 1980-2000 (Amsterdam: Rozenberg Publishcrs, 2002). 
montoneras of the 1920s, ronderos of the 1980s and 1990s were fighting against unjust abuses and their victimization. But unlike the montoneras of the 1920s, the ronderos were fighting not against official government authorities and their private representatives, but instead against men and women who aimed to seize government for themselves. And while the Peruvian state under Augusto B. Leguía saw the montoneras as a threat to be repressed with violence and arrests, the governments of the late 1980s and early 1990s understood that Peru's chance for peace lay in arming and supporting the ronderos. Like the montoneras of the 1920 s, ronderos of the 1980s and 1990s used militarized organization and tactics to fight political figures whose actions they believed were "bad for the Pueblo."130

Dalhousie University

Jaymie Patricia Heilman

Halifax, Nova Scotia, Canada 